\title{
Efek Deksametason pada Homeostasis Kalsium dan Ekspresi Transforming Growth Factor Beta-1 Tulang Femur Tikus Wistar Pasca Transplantasi Menggunakan Demineralized Freeze-Dried Bovine Bone Xenograft
}

(THE EFFECT OF DEXAMETHASONE ON CALCIUM HOMEOSTASIS AND THE EXPRESSION OF TGF- 1 I OF WISTAR RAT'S FEMUR BONE POST TRANSPLANTATION WITH DEMINERALIZED FREEZE-DRIED BOVINE BONE XENOGRAFT)

\author{
Luh Made Sudimartini ${ }^{1 *}$, Dhirgo Adji ${ }^{2}$, Hastari Wuryastuty ${ }^{3}$ \\ ${ }^{1}$ Laboratorium Farmasi Fakultas Kedokteran Hewan Universitas Udayana Jln. PB. Sudirman \\ Denpasar Bali; \\ ${ }^{2}$ Bagian Ilmu Bedah dan Radiologi Fakultas Kedokteran Hewan, Universitas Gadjah Mada, \\ Yogyakarta; \\ ${ }^{3}$ Bagian Ilmu Penyakit Dalam Fakultas Kedokteran Hewan, Universitas Gadjah Mada \\ Yogyakarta. \\ *Email: ocha_manja82@yahoo.co.id
}

\begin{abstract}
Abstrak
Penelitian ini bertujuan untuk mempelajari tingkat keamanan penggunaan deksametason sebagai anti radang dan analgetika pada penanganan fraktur tulang femur tikus dengan metode cangkok tulang. Sampel yang digunakan adalah 32 ekor tikus Wistar jantan umur dua bulan dibagi menjadi dua kelompok secara acak, masing-masing kelompok 16 ekor tikus. Kelompok I (kontrol) adalah tikus yang dibuat fraktur dan difiksasi dengan pin intramedular tanpa pemberian bahan cangkokan sedangkan tikus kelompok II adalah tikus yang dibuat fraktur dan difiksasi dengan pin intramedular dan diberikan bahan cangkokan demineralized freeze dried bovine bone xenograft (DFDBBX). Tikus Kelompok I dan II selanjutnya dibagi lagi menjadi dua kelompok, yaitu Kelompok IA, IB, IIA dan IIB masing masing delapan ekor tikus. Tikus A adalah tikus yang tidak diinjeksi dengan deksametason, sedangkan tikus $B$ adalah tikus yang diinjeksi deksametason dengan dosis $0,5 \mathrm{mg} / \mathrm{Kg}$ $\mathrm{BB} /$ hari pasca operasi. Pada akhir minggu I, delapan ekor tikus dari kelompok I (A,B) dan II(A,B) (masing-masing kelompok dua ekor tikus) diambil darahnya untuk analisis total leukosit dan kalsium darah. Sampel urin juga dikoleksi untuk pemeriksaan kalsium urin. Tikus selanjutnya dieuthanasi, tulang femur dikoleksi untuk pemeriksaan histopatologis dan imunohistokimia terhadap ekspresi Transforming Growth Factor- $\beta 1$ (TGF-. B1) menggunakan metode Streptavidin-biotin.. Pengambilan sampel berturut-turut selanjutnya dilakukan pada akhir minggu ke-2, 4 dan 8 perlakuan. Data total leukosit, kalsium darah dan urin dianalisis secara statistik menggunakan pola faktorial $2 \times 2 \times 4$ sedangkan analisis histopatologis dan imunohistokimia dilakukan secara deskriptif. Hasil analisis statistik pola faktorial dari data konsentrasi kalsium urin, menunjukkan adanya pengaruh yang signifikan dari pemberian deksametason, penggunaan bahan cangkok dan lamanya perlakuan $(\mathrm{p}<0,05)$, sedangkan hasil analisis statistik terhadap konsentrasi kalsium darah tidak berbeda nyata ( $>0,05)$. Hasil analisis statistik terhadap total leukosit, menunjukkan bahwa terdapat pengaruh yang signifikan pada pemasangan bahan cangkok $(\mathrm{p}<0,05)$. Analisis histopatologis jaringan tulang menunjukkan terjadinya peningkatan infiltrasi sel-sel radang pada kelompok tikus yang tidak diinjeksi deksametason. Sedangkan hasil analisis imunohistokimia menunjukkan ekspresi positif TGF- $\beta 1$ pada semua kelompok perlakuan. Berdasarkan hasil yang diperoleh, disimpulkan bahwa injeksi deksametason pasca operasi orthopedi dengan maupun tanpa penggunaan Demineralized Fried-Dried Bovine Bone Xenograft (DFDBBX) mampu mengurangi radang, namun dapat mengganggu proses kesembuhan fraktur.
\end{abstract}

Kata kunci: Fraktur; demineralized freeze-dried bovine bone xenograft; deksametason; homeostasis kalsium; TGF- $\beta 1$ 


\begin{abstract}
This research aims to evaluate the safety of dexamethasone use as an anti-inflammatory and analgesic on the handling of femur fracture of rats by bone graft method. The sample used was 32 male Wistar rats aged 2 months were divided into two groups, 16 rats for each. Group I was fractured rats and fixed with intramedullary pin without bone graft, whereas Group II was fractured and fixed with intramedullary pin and demineralized freeze-dried bovine bone xenograft (DFDBBX). Group I and II were then divided into two groups for each, Group IA, IB, IIA, and IIB, eight rats for each. Group IA and IIA were not injected with dexamethasone, whereas Group IB and IIB were injected with dexamethasone $0.5 \mathrm{mg} / \mathrm{kg} \mathrm{BW} /$ day intramuscularly. At the end of the first week, blood was collected from eight rats (two rats for each) of Group IA, IIA, IB, and IIB for total leucocytes and blood Calcium analysis. Urine was also collected for urine Calcium analysis. Rats were then killed to collect the femur for histopathologic analysis using HE staining and immunohistochemistry to analyze the expression of TGF $\beta-1$ using Streptavidin-biotin method. Subsequent sampling was conducted at the end of 2nd, 4th, and 8th weeks of treatment, respectively. The total data of leucocytes, blood, and urine Calcium were statistically analyzed using a $2 \times 2 \times 4$ factorial method, while the histopathologic and immunohistochemistry specimens were analyzed descriptively under the microscope based on the alteration of the bones. The statistical analysis showed that dexamethasone increased the concentration of urine Calcium $(p<0,05)$, the concentration of blood Calcium insignificantly $(p>0,05)$ affected by dexamethasone but cause homeostatic calcium disorder and the total leucocytes significantly $(\mathrm{p}<0,05)$ affected by grafted materials. Histopathologic analysis of the femur showed that there was an increased infiltration of inflammatory cells in the fracture area from the group untreated with dexamethasone. Whereas the immunohistochemistry analysis showed positive results from all groups. Based on the whole analysis, it can be concluded that although dexamethasone depressed inflammation process, it can also disturb the fracture healing process.
\end{abstract}

Keywords: Fracture; Demineralized Freeze-Dried Bovine Bone Xenograft (DFDBBX); dexamethasone; calsium homeostasis; TGF- $\beta 1$

\section{PENDAHULUAN}

Fraktur merupakan terputusnya kontinuitas jaringan tulang dan tulang rawan yang umumnya disebabkan oleh trauma, baik secara langsung maupun tidak langsung (Hamish and Steven, 2000). Dalam kebanyakan kasus, pemulihan keselarasan dan fiksasi tulang sangat diperlukan untuk mencapai kesuksesan dari rekonstruksi tulang. Tindakan pencangkokan tulang atau transplantasi diperlukan untuk merangsang proses penyembuhan tulang dan untuk mengisi bagian tulang yang hilang (Finkemeier, 2002). Bahan cangkok tulang yang ideal harus memiliki potensial untuk mempertahankan sel tetap hidup, tidak menimbulkan reaksi imunologi, mudah didapat dan memberi kekuatan sekeliling tulang serta tidak menyebarkan penyakit (Becker et al., 1998). Demineralized freeze-dried bovine bone xenograft (DFDBBX) merupakan salah satu jenis bahan cangkok yang dibuat dengan proses skrining yang ketat (Yunanthi et al., 2010) dan mampu memperbaiki kerusakan tulang yang besar karena sifat osteokonduktif yang tinggi dengan cara melepas ion kalsium (Maiorama and Simon, 2003; Stephan et al., 1999).

Dalam penanganan trauma, hewan akan merasakan nyeri akibat peradangan. Deksametason sebagai salah satu obat golongan kortikosteroid sering digunakan sebagai obat antiinflamasi dan autoimun (Yasear and Hamouda, 2009). Meskipun demikian, pemberian deksametason harus dipertimbangkan sejak awal terapi, terutama menyangkut cara pemberian, dosis dan lama pemberian, mengingat efek samping yang ditimbulkan akibat pemberian deksametason antara lain osteoporosis (Ratna, 2011). Kortikosteroid dapat menyebabkan terjadinya penurunan kalsium darah melalui penghambatan absorpsi kalsium oleh usus halus dan peningkatan ekskresi kalsium di urin, yang dapat menstimulasi sekresi hormon 
paratiroid sehingga terjadi peningkatan osteoklas dan absorbsi tulang. Hal ini ditujukan untuk memperbaiki keseimbangan kalsium serum, namun menyebabkan penurunan densitas tulang (Poetker and Reh, 2010).

Berdasarkan hal tersebut, pada penelitian ini akan diteliti tentang efek pemberian deksametason pada homeostasis kalsium dan ekspresi transforming growth factor beta-1 pada penanganan fraktur tulang femur tikus Wistar dengan metoda cangkok tulang dan pinning intrameduler.

\section{METODE PENELITIAN}

Dalam penelitian ini digunakan 32 tikus Wistar jantan umur dua bulan. Pakan yang diberikan pada tikus percobaan selama penelitian berupa pakan standard (normal protein, lemak dan karbohidrat). Tikus kemudian dibagi menjadi dua kelompok secara acak, masing-masing 16 ekor. Tikus kelompok I adalah tikus yang dipergunakan sebagai kontrol, yaitu tikus yang dibuat fraktur dan difiksasi dengan pin intramedular dan tanpa pemberian bahan cangkok (tanpa DFDBBX), tikus kelompok II adalah tikus yang dibuat fraktur dan difiksasi menggunakan pin intramedular dan diberikan bahan cangkok (dengan DFDBBX). Tikus pada kelompok I dan II selanjutnya dibagi lagi menjadi dua kelompok masing-masing 8 ekor tikus. Tikus kelompok IA, yaitu tikus yang tanpa diberikan preparat deksametason dan kelompok IB yaitu tikus yang diberikan preparat deksametason. Tikus kelompok IIA, yaitu tikus yang diberikan bahan cangkok dan tanpa pemberian preparat deksametason. Tikus kelompok IIB, yaitu tikus yang diberi bahan cangkok dan preparat deksametason. Pemberian preparat deksametason diberikan secara intramuskuler terus menerus pasca operasi dengan dosis pemberian $0,5 \mathrm{mg} / \mathrm{Kg} \mathrm{BB} /$ hari. Monitoring perkembangan kesembuhan dilakukan berturut-turut pada minggu ke-1, ke-2, ke-4 dan ke-8 pasca operasi, dua ekor tikus dipilih dari masing- masing kelompok (total : delapan ekor). Tikus kemudian diambil darahnya untuk pemeriksaan jumlah total leukosit dan konsentrasi kalsium dalam darah. Sampel urin juga dikoleksi untuk pemeriksaan konsentrasi kalsium dalam urin. Kalsium serum dan urin diperiksa dengan metoda O-Cresopthalein-Complex (OCPC). Setelah itu tikus dietanasi untuk pengambilan tulang femur. Perlakuan yang sama dilakukan pada tikus sisa berturutturut setelah minggu ke- 2 , ke-4 dan ke- 8 perlakuan. Tulang femur yang sudah diambil, disimpan dalam larutan formalin $10 \%$ untuk dibuat preparat histopatologis (sesuai standar Laboratorium Patologi Balai Besar Veteriner Regional VI Denpasar) dengan pengecatan Hematoksilin Eosin untuk melihat perubahan yang ada pada tulang, dan sebagian digunakan untuk preparat imunohistokimia guna melihat ekspresi TGF- $\beta 1$ dengan metoda StreptavidinBiotin pada daerah yang dicangkok. Preparat histopatologis dan imunohistokimia dianalisis secara deskriptif dengan melihat perubahan yang terjadi pada organ. Preparat imunohistokimia dianalisis dengan melihat ikatan antigen-antibodi yang berwarna coklat tua.

\section{HASIL DAN PEMBAHASAN}

\section{Konsentrasi kalsium urin}

Hasil analisis statistik pola faktorial dari data konsentrasi kalsium urin, menunjukkan adanya pengaruh yang signifikan dari pemberian deksametason, penggunaan bahan cangkok dan lamanya perlakuan $(\mathrm{P}<0,05)$. Hasil data yang diperoleh dari penelitian ini menunjukkan bahwa konsentrasi kalsium urin lebih tinggi pada kelompok tikus yang diberi deksametason. Deksametason merupakan obat golongan kortikosteroid yang dapat menyebabkan terjadinya penurunan kalsium darah melalui penghambatan absorbsi kalsium oleh usus halus dan peningkatan ekskresi kalsium urin (Poetker and Reh, 2010). Tingginya konsentrasi 
kalsium urin juga dapat disebabkan oleh pengaruh berbagai faktor antara lain konsentrasi kalsium dalam plasma, ekskresi hormon kalsitonin, defisiensi fosfor yang serius, asidosis yang terjadi karena proses metabolisme yang terganggu, vitamin D, hormon glukokortikoid (Poetker and Reh, 2010) dan hormon paratiroid (Djojosoebagio, 1990). Kalsium yang diekskresikan melalui urin merupakan suatu mekanisme aktif ginjal dalam melakukan reabsorbsi terhadap kalsium (Yuniarti et al., 2008).

Hasil analisis statistik konsentrasi kalsium urin terhadap faktor penggunaan bahan cangkok menunjukkan perbedaan yang sangat signifikan $(\mathrm{P}<0,05)$. Bahan cangkok dalam penelitian ini digunakan sebagai penginduksi sel-sel mesenkimal untuk berdiferensiasi menjadi osteoblas sehingga proses kesembuhan tulang lebih cepat terjadi (Bolander, 1992). Bahan cangkok DFDBBX memiliki sifat fisik yang mirip dengan mineral tulang manusia (Baharuddin et al., 2005). Selain memiliki sifat osteoinduksi, DFDBBX juga memiliki sifat oseteogenik karena adanya sejumlah protein yang terkandung didalamnya (Plata et al., 2002). Potensi osteogenik dan osteoinduksi dari bahan cangkok sangat diharapkan pada proses demineralisasi karena tanpa adanya kemampuan osteogenik dan osteoinduksi maka bahan cangkok hanya berfungsi sebagai space maintener saja atau berlaku sebagai pembawa komponen biaktif seperti BMP (Masulili et al., 2008). Di dalam penelitian ini, secara teori maupun kenyataan bahan cangkok tidak terkait dengan peningkatan ekskresi kalsium melalui urin. Peningkatan kalsium yang terkait dengan pemberian bahan cangkok merupakan suatu kesalahan data yang tidak diketahui penyebabnya, karena sepanjang pemahaman tidak akan ada pengaruh bahan cangkok pada homeostasis kalsium. Meskipun demikian, adanya kenyataan bahwa pemberian bahan cangkok secara statistik meningkatkan ekskresi kalsium urin perlu dikaji lebih lanjut.

Hasil analisis statistik menunjukkan adanya hubungan antara ekskresi kalsium urin dengan waktu perlakuan $(\mathrm{P}<0,05)$. Semakin lama waktu pemberian deksametason akan semakin meningkatkan konsentrasi kalsium yang diekskresikan melalui urin. Dalam teori homeostasis kalsium, semakin banyak kalsium yang diekskresikan melalui urin, maka akan semakin banyak pula Paratiroid hormone (PTH) yang dihasilkan oleh kelenjar paratiroid dengan tujuan untuk mengaktifkan osteoklas dalam menyerap bagian tulang yang telah mengalami mineralisasi (Bullock and Rosendahl, 1984).

\section{Konsentrasi kalsium serum}

Hasil analisis statistik pola faktorial terhadap konsentrasi kalsium serum menunjukkan bahwa tidak ada perbedaan yang nyata $(\mathrm{P}>0,05)$ pada semua kelompok perlakuan. Interaksi diantara kelompok perlakuan dan lamanya perlakuan menunjukkan tidak ada perbedaan yang signifikan $(\mathrm{P}>0,05)$.

Tikus Kelompok IB memiliki konsentrasi kalsium yang paling tinggi dibandingkan kelompok lain pada minggu pertama. Konsentrasi kalsium serum pada kelompok IB melebihi batas normal konsentrasi kalsium dalam darah yang menurut Bullock and Rosendahl (1984), konsentrasi kalsium normal dalam darah adalah 9,2-10,4 mg/dl. Terjadinya peningkatan konsentrasi kalsium tersebut belum dapat disebut sebagai hiperkalsemia, karena dengan adanya perubahan $1-5 \%$ dari kalsium darah menyebabkan mekanisme homeostasis mulai berperan untuk mengembalikan konsentrasi kalsium pada konsentrasi yang normal (Smith et al., 1983; Cunningham, 1992).

Kelompok IB dan IIB mengalami penurunan konsentrasi $\mathrm{Ca}$ serum dari minggu pertama. Hal ini disebabkan karena penggunaan deksametason yang dapat mengakibatkan terjadinya penurunan 
konsentrasi kalsium serum dan peningkatan ekskresi kalsium melalui urin. Terjadinya penurunan konsentrasi kalsium serum dapat memicu kelenjar paratiroid untuk memproduksi PTH yang akan berefek pada 3 mekanisme yaitu: (1) Mobilisasi kalsium dari tulang, (2) meningkatkan absorbsi kalsium di usus halus dan (3) meningkatkan reabsorbsi kalsium dalam ginjal. Yuniwarti dan Saraswati (2002) menyebutkan bahwa kalsium dalam darah berperan pada proses kalsifikasi yaitu terjadinya endapan mineral kalsium fosfat dalam jaringan osteoid. Penurunan konsentrasi kalsium dalam darah akan menyebabkan tidak terjadinya mineralisasi pada tulang sehingga akan mempengaruhi bentuk tulang.

Secara analisis statistik, tidak terjadi perbedaan yang nyata terhadap konsentrasi kalsium serum akibat pemberian deksametason. Namun, dengan tingginya ekskresi kalsium melalui urin menyebabkan terjadinya gangguan homeostasis kalsium, karena untuk mempertahankan konsentrasi kalsium dalam darah tetap normal akan terjadi resorpsi kalsium di tulang. Penurunan pembentukan tulang dan peningkatan resorpsi akhirnya akan menyebabkan osteopenia yang mungkin menjadi komplikasi utama dari deksametason berlebihan spontan ataupun iatrogenik.

\section{Total leukosit}

Hasil analisis statistik pola faktorial terhadap jumlah leukosit menunjukkan bahwa terjadi perbedaan yang signifikan pada kelompok tikus yang diberi bahan cangkok $(\mathrm{P}<0,05)$. Hal ini disebabkan karena pemberian bahan cangkok yang dianggap sebagai benda asing oleh tubuh dapat memicu terjadinya peradangan sehingga terjadi peningkatan leukosit, namun jumlah leukosit total yang terdapat dalam darah masih berada dalam batas normal. Leukosit merupakan bagian penting dari sistem pertahanan tubuh terhadap benda asing, mikroorganisme atau jaringan asing, sehingga hitung jumlah leukosit merupakan indikator yang baik untuk mengetahui respon tubuh terhadap infeksi termasuk penolakan terhadap materi asing (Bloom and Fawcet, 1994).

Hasil analisis statistik pola faktorial jumlah leukosit terhadap waktu perlakuan dan penggunaan deksametason menunjukkan bahwa tidak tejadi perbedaan yang nyata $(\mathrm{P}>0,05)$. Pada waktu pengambilan sampel minggu kedua, terjadi peningkatan total leukosit untuk semua kelompok perlakuan, hal ini disebabkan karena pada minggu kedua masih merupakan fase inflamasi dari kesembuhan tulang dan respon terhadap adanya benda asing dimana sel-sel leukosit seperti neutrofil, fibroblas dan makrofag masih berperan.

Berdasarkan hasil statistik yang diperoleh, tidak adanya perbedaan yang nyata pada rerata total leukosit terhadap waktu pengambilan dan penggunaan deksametason pada semua perlakuan dari minggu pertama sampai minggu kedelapan mengindikasikan bahwa tidak ada reaksireaksi negatif yang diharapkan seperti penolakan terhadap bahan cangkok, walaupun dalam penggunaan bahan cangkok terjadi perbedaan yang nyata.

\section{Histopatologis tulang}

Hasil pemeriksaan preparat histopatologis tulang pada minggu pertama dapat dilihat pada Gambar 1. Berdasarkan pemeriksaan histopatologis, pada minggu pertama ditemukan adanya infiltrasi sel radang di sekitar daerah patahan untuk semua kelompok. Hal ini disebabkan karena pada minggu pertama masih merupakan fase inflamasi pada proses kesembuhan fraktur. Fase inflamasi dapat terjadi 1-2 minggu pasca operasi (Pilitsis et al., 2002). Adanya infiltrasi sel radang juga ditemukan pada kelompok tikus dengan pemberian deksametason, baik yang diberikan bahan cangkok DFDBBX dan tanpa DFDBBX. Infiltrasi sel radang pada tikus Kelompok IB lebih sedikit 
dibandingkan dengan tikus yang tidak menggunakan bahan cangkok dan tanpa pemberian deksametason. Begitu juga pada tikus Kelompok IIB, infiltrasi sel radang lebih sedikit terjadi dibandingkan dengan tikus Kelompok IIA. Hal ini disebabkan karena deksametason dapat menghambat semua fase respon inflamasi termasuk pembengkakan, kemerahan dan sakit serta proliferasi pada inflamasi kronik. Inflamasi ditekan dengan mekanisme yang luas. Kerja utama obat antiradang glukokortikoid menghambat pembebasan asam arakidonat melalui penghambatan secara tidak langsung enzim fosfolipase $\mathrm{A}_{2}$ dengan menginduksi sintesis protein G/lipokortin G (Campbell,
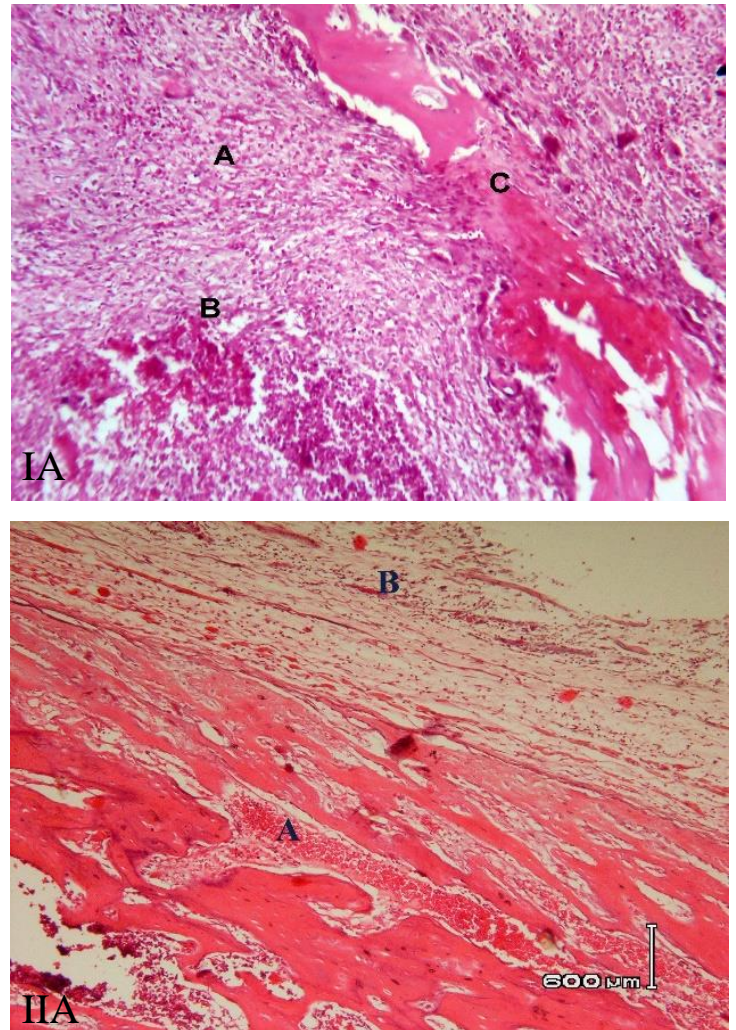

1991). Selain menghambat pembebasan asam arakidonat yang mengakibatkan terhambatnya sintesis prostaglandin dan leukotrien, glukokortikoid juga menghambat platelet activating factor (PAF), tumor necrosis factor (TNF) dan interleukin-1 (IL-1) (Haynes, 1991). Interleukin-1 mempunyai peranan penting pada aksi radang antara lain menstimulasi prostaglandin dan kolagenase, mengaktivasi limfosit $\mathrm{T}$, menstimulasi proliferasi fibroblas kemotraktan leukosit dan menyebabkan neutrofilia. Glukokortikoid juga menghambat pembentukan aktivator plasminogen oleh neutrofil (Haynes, 1991).
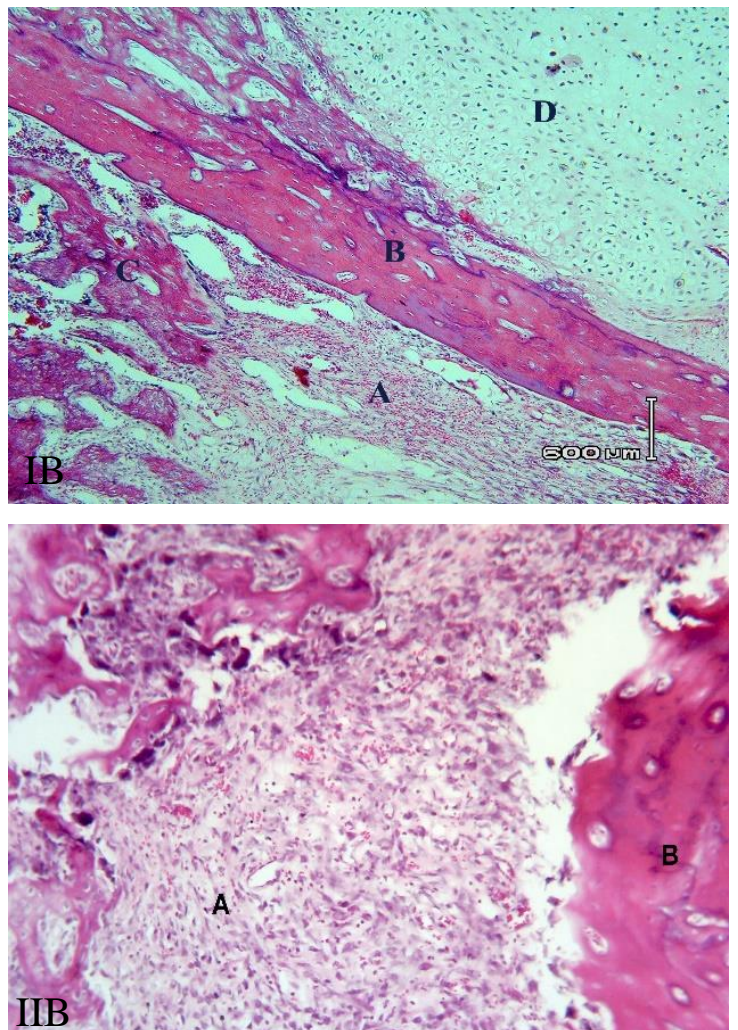

Gambar 1. Gambaran histopatologis tulang tikus wistar masing-masing perlakuan pada minggu pertama (HE, 500x.). Pada Kelompok IA terlihat proliferasi fibroblas disertai adanya infiltrasi neutrofil (A), hemoragis (B) dan korteks tulang (C). Pada Kelompok IB terlihat adanya hemoragis pada jaringan fibroblas (A), korteks tulang (B), trabekula (C) dan infiltrasi neutrofil pada jaringan kartilago (D). Pada Kelompok IIA terlihat adanya kongesti dan hemoragis pada sumsum tulang (A) dan infiltrasi neutrofil (B). Pada Kelompok IIB terlihat adanya proliferasi fibroblas (A) dan korteks tulang (B).

Hasil pemeriksaan preparat histopatologis tulang pada minggu kedua dapat dilihat pada Gambar 2. Pada minggu kedua, pemeriksaan histopatologis menunjukkan terjadinya proliferasi jaringan fibroblas dan kartilago pada semua kelompok dan lebih cepat terjadi pada kelompok yang diberi bahan cangkok 
DFDBBX. Hal ini disebabkan karena selain mengandung BMP suatu protein hydrophobic dalam matriks tulang yang mempengaruhi diferensiasi sel mesenkim menjadi osteoblas dan kondroblas yang ikut dalam proses penyembuhan tulang baru, DFDBBX juga mengandung platelet derived growth factor (PDGF) dan fibroblas growth factor (FGF) sehingga
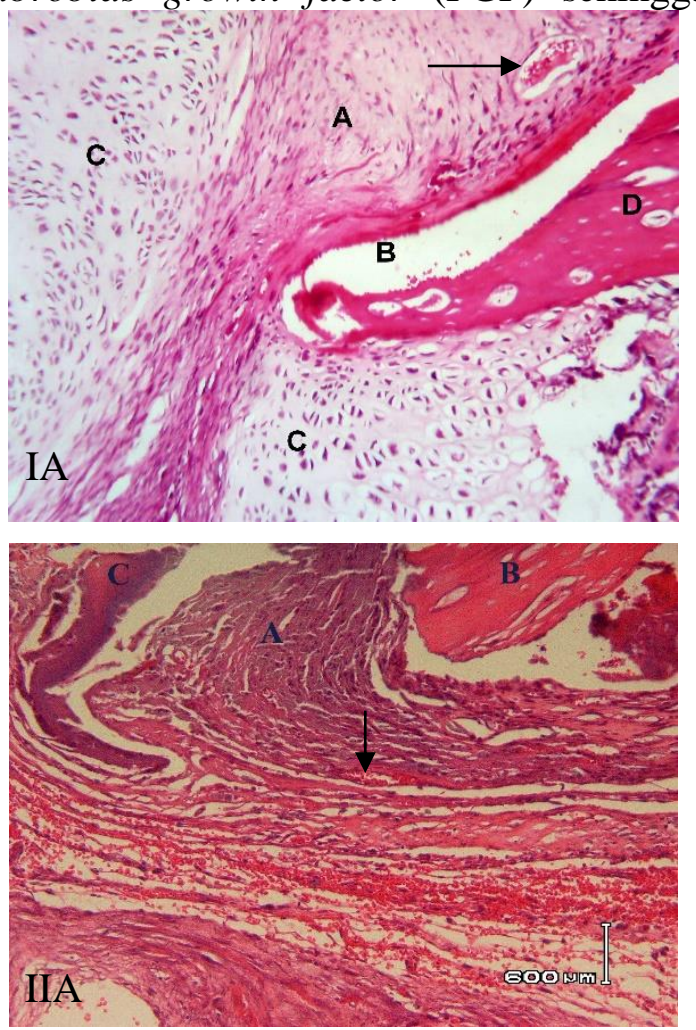

proliferasi fibroblas lebih cepat terpacu dan pembentukan kartilago lebih luas (Wildmann et al., 2007). Selain itu mengandung vascular endothelial growth factor (VEGF), yang memicu proses vaskularisasi hal ini sesuai dengan hasil penelitian pada minggu kedua dan keempat.

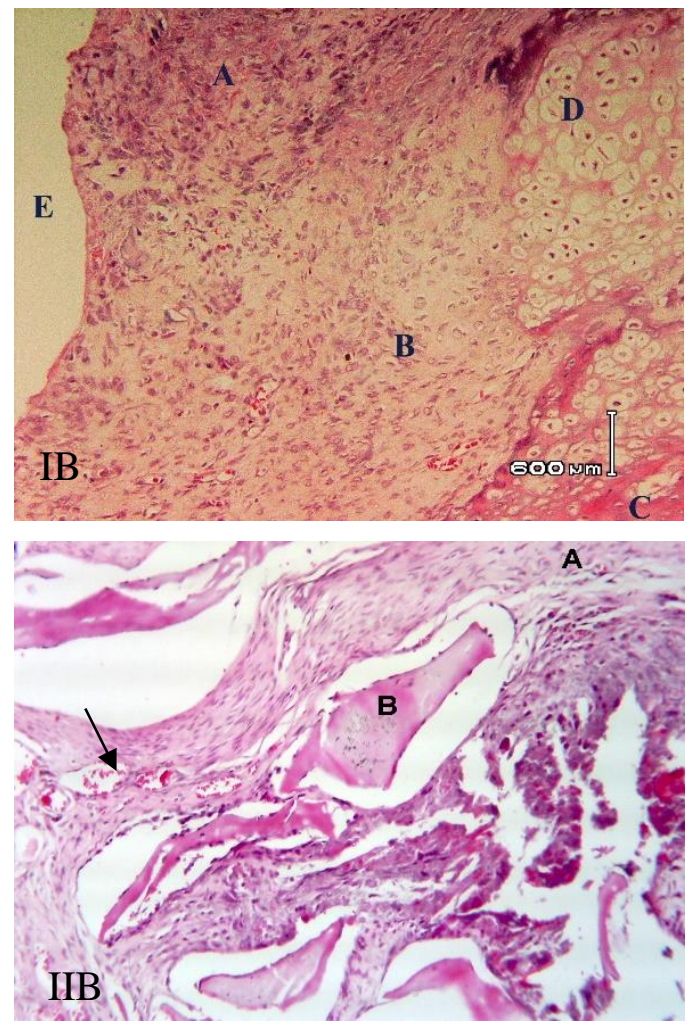

Gambar 2. Gambaran histopatologis tulang tikus wistar masing-masing perlakuan pada minggu kedua (H\&E, 500x.). Pada kelompok IA terlihat adanya proliferasi fibroblas (A), gap fraktur (B), proliferasi kondroblas (C), korteks tulang (D) dan neovaskularisasi (anak panah). Pada Kelompok IB terlihat nekrosis (A), proliferasi fibroblas (B), trabekula (C), proliferasi kondroblas (D), gap fraktur (E) dan neovaskularisasi. Pada Kelompok IIA terlihat adanya jaringan fibroblas (A), korteks tulang (B), graft DFDBBX (C) dan neovaskularisasi (anak panah). Pada Kelompok IIB terlihat adanya jaringan fibroblas (A), graft DFDBBX (B) dan neovaskularisasi (anak panah).

Pada minggu keempat (Gambar 3), DFDBBX sudah mengalami degradasi namun belum sempurna. DFDBBX terdegradasi secara sempurna terjadi pada minggu kedelapan, hal ini sesuai dengan penelitian yang dilakukan oleh Puricelli et al. (2010), dimana demineralized bone graft mampu terdegradasi dengan baik mulai 30-60 hari pasca implantasi. Hasil pemeriksaan preparat histopatologis tulang pada minggu kedelapan dapat dilihat pada Gambar 4.

Pada minggu kedelapan DFDBBX sudah terdegradasi secara sempurna namun belum mengalami mineralisasi tulang, hal ini disebakan karena DFDBBX tidak mengandung kalsium dan fosfor (Plata $e t$ al., 2002). Pada Kelompok IIA masih terlihat adanya infiltrasi sel neutrofil. Hal ini kemungkinan disebabkan karena terjadinya infeksi sekunder ditandai 
dengan adanya daerah yang mengalami nekrosis dan dari pemeriksaan total leukosit juga terjadi peningkatan pada minggu kedelapan. Menurut Kaewloet (2008), infiltrasi neutrofil terjadi pada hari 2-4 pasca terjadinya luka, dan hal ini distimulasi oleh trombosit yang dilepaskan saat terjadi luka untuk menarik sel-sel radang tersebut ke daerah luka. Neutrofil
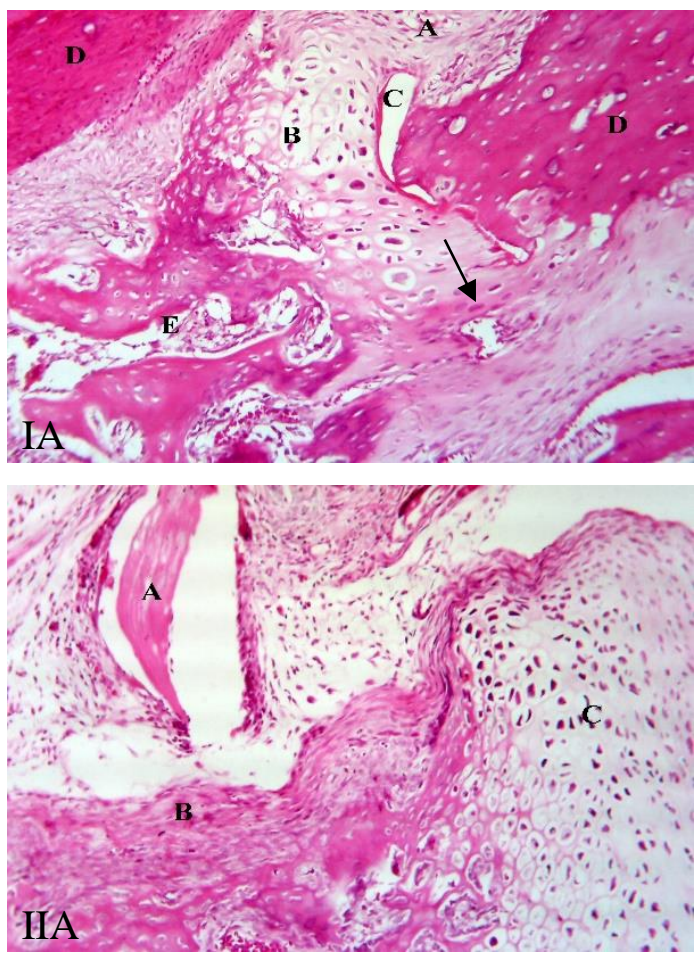

disini berfungsi untuk membunuh atau memfagositosis bakteri serta kontaminan yang masuk ke daerah luka (Rozman and Bolta, 2007). Menurut Lorenz and Longaker (2005), jumlah infiltrasi neutrofil akan menurun pada luka bekas operasi yang aseptis dibandingkan pada luka yang terkontaminasi maupun luka yang terinfeksi.
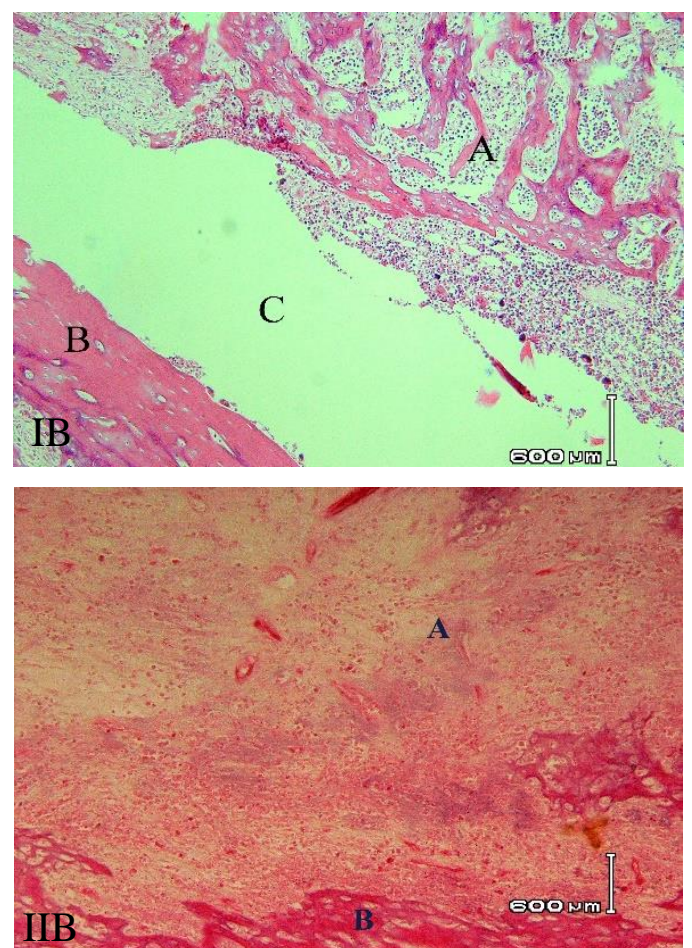

Gambar 3. Gambaran histopatologis tulang tikus wistar masing-masing perlakuan pada minggu keempat (H\&E, 500x.). Pada Kelompok IA terlihat adanya proliferasi fibroblas (A), proliferasi kondroblas (B), gap fraktur (C), korteks tulang (D), trabekula (E) dan neovaskularisasi (anak panah). Pada Kelompok IB terlihat adanya infiltrasi neutrofil pada sumsum tulang (A). Pada Kelompok IIA terlihat adanya bahan cangkok DFDBBX yang belum terdegradasi sempurna (A), proliferasi fibroblas (B), proliferasi kondroblas (C) dan neovaskularisasi (anak panah). Pada Kelompok IIB terlihat adanya bahan cangkok DFDBBX yang sudah terdegradasi sempurna (A) dan trabekula (B).

\section{Analisis imunohistokimia pada tulang}

Hasil analisis imunohistokimia untuk melihat ekspresi TGF- $\beta 1$ pada tulang tikus dalam tiap kelompok menggunakan metode streptavidin-biotin ditunjukkan pada Gambar 5. Uji imunohistokimia digunakan untuk melihat adanya ikatan antigen-antibodi yang diekspresikan pada jaringan dalam bentuk visualisasi warna coklat tua (kromogen) (Werner and Grose, 2003).

Hasil yang positif menandakan bahwa suatu jaringan mengekspresikan suatu antigen terhadap antibodi anti TGF- $\beta 1$ yang diberikan pada saat dilakukan uji tersebut. Hasil uji imunohistokimia pada jaringan tulang terhadap ekspresi TGF- $\beta 1$ menunjukkan bahwa ekspresi TGF- $\beta 1$ terdapat pada semua kelompok perlakuan. Transforming growth factor $\beta 1$ (TGF- $\beta 1$ ) merupakan sitokin yang berperan dalam berbagai proses homeostasis dan perbaikan jaringan (Werner and Grose, 2003) sedangkan menurut $\mathrm{Wu}$ et al. (2010), TGF- $\beta 1$ merupakan stimulator terkuat dalam mempengaruhi perbaikan sel pada 
setiap fase kesembuhan dan memainkan peran penting dalam remodelling tulang (Tzakas et al., 2005). Di dalam tubuh, konsentrasi tertinggi TGF- $\beta 1$ ditemukan dalam tulang dan kartilago (Chen et al., 2012) serta trombosit (Virolainen et al., 1998) dan akan disekresikan dalam jumlah besar oleh trombosit sesaat setelah terjadinya luka, dimana TGF- $\beta 1$ tersebut berperan sebagai kemoatraktan bagi sel-sel radang seperti neutrofil, makrofag dan fibroblas. Sel-sel radang tersebut mempunyai efek positif terhadap TGF- $\beta 1$ karena sel-sel tersebut akan memproduksi lebih banyak lagi TGF- $\beta 1$ untuk lebih
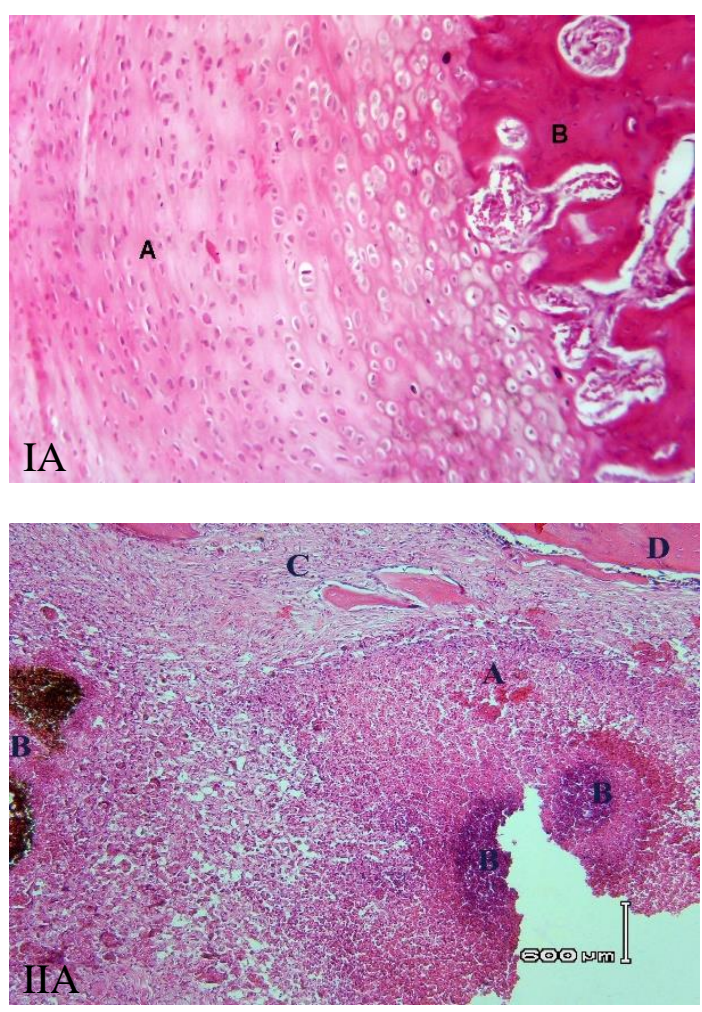

meningkatkan aksinya (Faler et al., 2006). Berbagai data dari penelitian eksperimental invivo menunjukkan bahwa TGF- $\beta 1$ berperan pada setiap formasi tulang dan secara invitro dapat meningkatkan formasi tulang dengan cara merangsang proliferasi dari sel-sel progenitor osteoblas, dan selanjutnya memungkinkan peningkatan sekumpulan sel-sel yang terprogram akan menjadi osteoblas, sedemikian rupa dengan cara meningkatkan diferensiasi produksi matriks tulang pada tahap awal (Janssen et al., 2005; Chen et al., 2012).
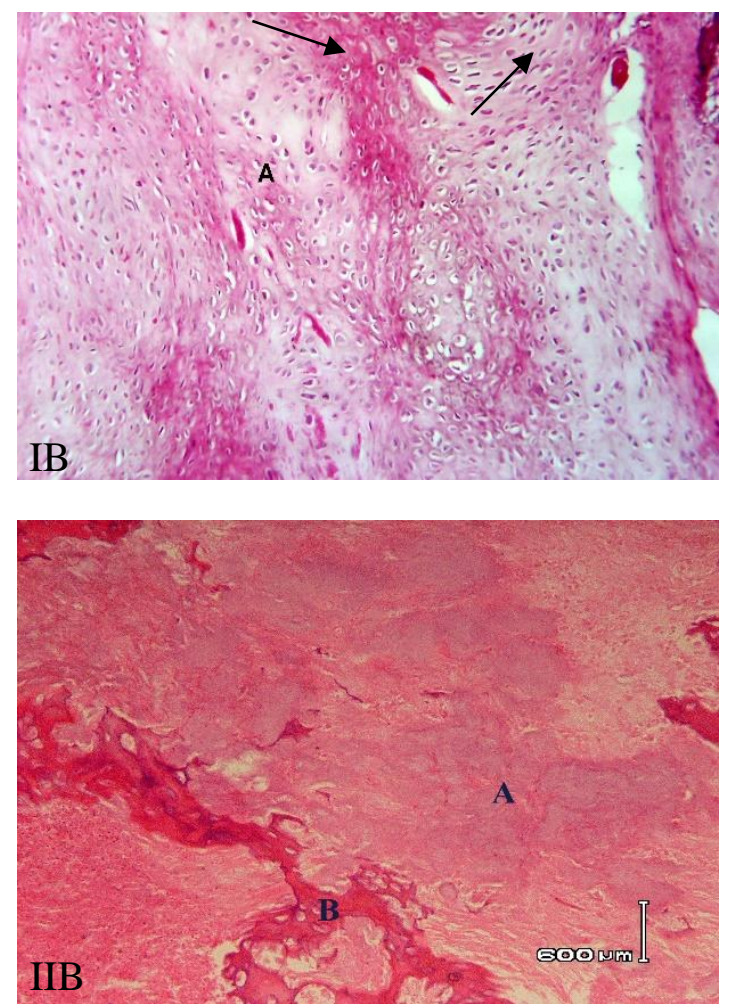

Gambar 4. Gambaran histopatologis tulang tikus wistar masing-masing perlakuan pada minggu kedelapan (H\&E, 500x.). Pada Kelompok IA terlihat adanya kartilago yang belum mengalami mineralisasi (A) dan trabekula (B). Pada Kelompok IB terlihat adanya kartilago yang belum mengalami mineralisasi (A) dan neovaskularisasi (B). Pada Kelompok IIA terlihat adanya hemoragis (A), nekrosis (B), DFDBBX yang terdegradasi (C) dan korteks tulang (D). Pada Kelompok IIB terlihat adanya DFDBBX yang terdegradasi (A) dan trabekula (B). 

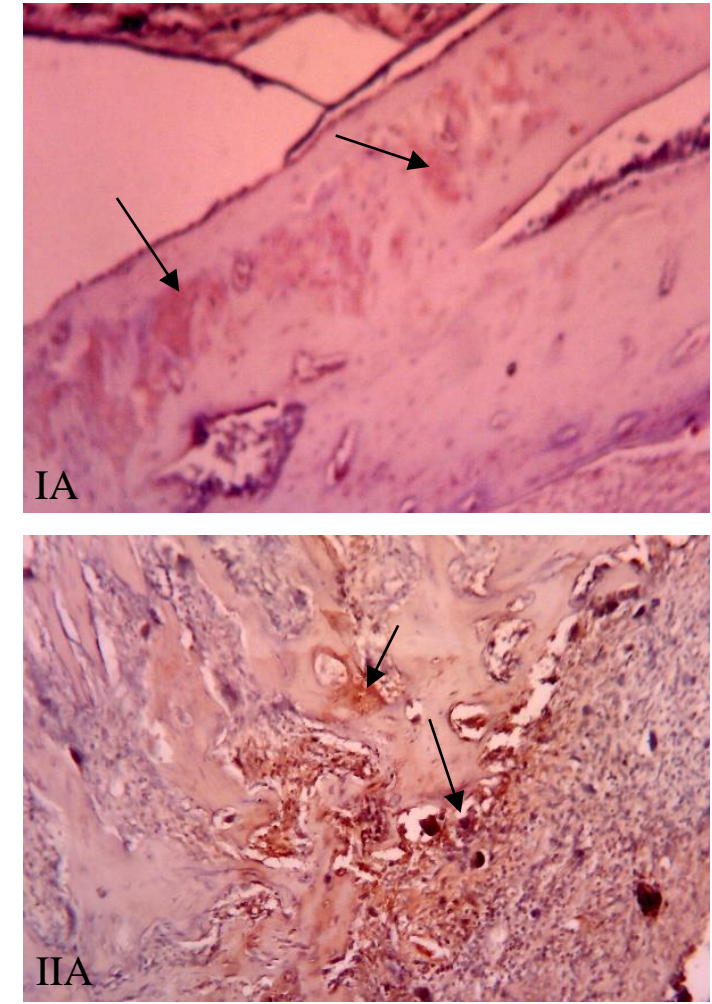
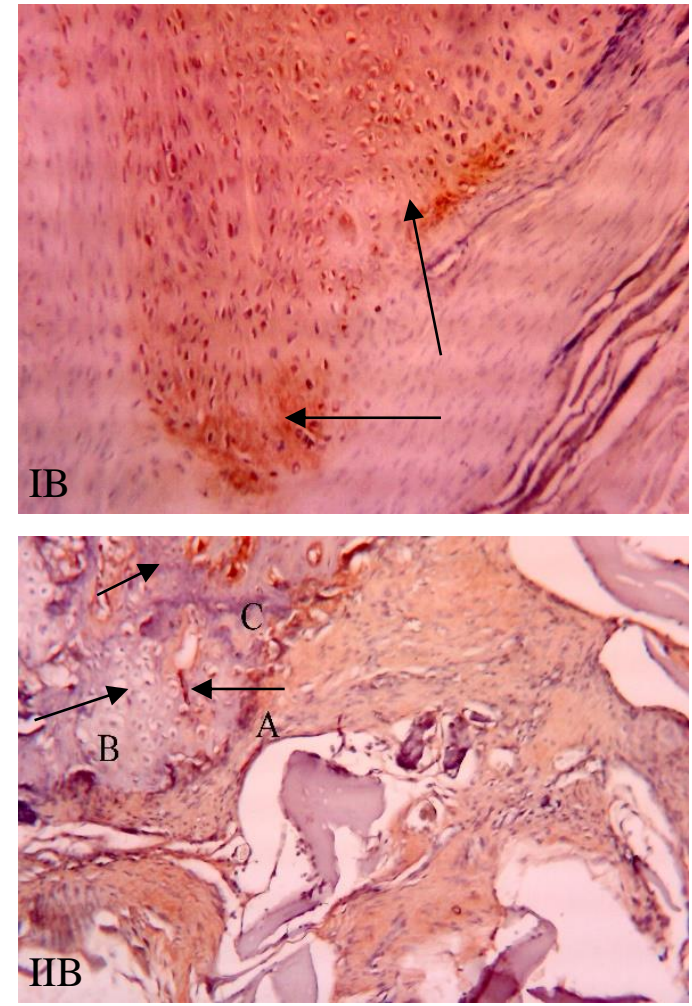

Gambar 5. Hasil analisis imunohistokimia tulang tikus Wistar pada masing-masing perlakuan (SAB, 500x). Pada Kelompok IA terlihat adanya reaksi positif pada korteks tulang (anak panah). Pada Kelompok IB terlihat adanya reaksi positif pada jaringan kartilago (anak panah). Pada Kelompo IIA terlihat adanya reaksi postif pada trabekula dan sumsum tulang (anak panah). Pada Kelompok IIB terlihat adanya reaksi positif pada jaringa fibroblas (A), kartilago (B) dan korteks tulang (C).

\section{SIMPULAN DAN SARAN}

\section{Simpulan}

Dari hasil penelitian yang telah dilakukan, maka dapat diambil kesimpulan bahwa deksametason dapat menekan sel radang, namun menganggu kesembuhan fraktur karena dapat meningkatkan ekskresi kalsium melalui urin, sehingga untuk mempertahankan konsentrasi kalsium darah dalam batas normal akan terjadi resorpsi kalsium di tulang.

\section{Saran}

Perlu dilakukan penelitian lebih lanjut untuk menyempurnakan hasil yang diperoleh dalam penelitian ini, termasuk penggunaan dosis deksametason rendah berulang atau lebih tinggi dan waktu pelaksanaan penelitian agar konsentrasi kalsium darah, kalsium urin dan total leukosit yang diperoleh berpengaruh pada kesembuhan tulang yang dibuat secara signifikan.

\section{UCAPAN TERIMAKASIH}

Penulis mengucapkan terimakasih kepada Dekan Fakultas Kedokteran Hewan Universitas Udayana, Direktur beserta staf dokter Rumah Sakit Hewan Pendidikan Universitas Udayana yang telah memfasilitasi dan membantu dalam pelaksanaan penelitian ini.

\section{DAFTAR PUSTAKA}

Baharuddin NA, Kamin S, Samsuddin AR. 2005. The use of demineralized freezedried bovine bone xenograft in reducing post-surgical periodontal recession. Annal. Dent. Univ. Malaya. 12: 37-40.

Becker W, Clokie C, Sannerby L, Urist MR, Becker BB. 1998. Histologic 
finding after implantation and evaluation of different grafting materials and titanium miro screws into extraction socket: case reports. $J$. Periodontal. 69: 414-21.

Bloom W, Fawcett D. 1994. A Textbook of Histology. $12^{\text {th }}$ Ed. Chapman and Hall. New York. Pp. 194-233.

Bolander ME. 1992. Regulation of fracture repair by growth factors. Pro. Soc. Exp. Biol. Med. 200: 165-170.

Bullock BL, Rosendahl PP. 1984. Pathophysiology Adaptations and Alterations in Function. Little, Brown and Company. Boston/Toronto. Pp. 547-577.

Campbell WB. 1991. Lipid-Derived Autacoids: Eicosanoids and PlateletActivating Factor. Dalam: Goodman and Gilman's The Pharmacological Basis of Therapeutics. Ed 8. Editor: Gilman, A.G. et al. New York: Pergamon Press. I, Pp. 600-611.

Chen G, Deng C, Li YP. 2012. TGF- $\beta$ and BMP signaling in osteoblast differentiation and bone formation. Int J. Biol. Sci. 8(2):272-288.

Cunningham, J.G. 1992. Teksbook of Veterinary Physiology. W.B. Saunders Company. Pp. 416-423

Djojosoebagio S. 1990. Fisologi Kelenjar Endokrin. Departemen pendidikan dan Kebudayaan. Direktorat jenderal Pendidikan Tinggi. Pusat Antar Universitas. Ilmu Hayati IPB. Pp. 147227.

Faler BJ, Mascata RA, Plummer D, Mishra L, Sidawy AN. 2006. Transforming growth factor B and wound healing. Perspect. Vasc. Surg. Endovasc. Ther. 18: 55.

Finkemeier CG. 2002. Bone grafting and bone graft substitutes. J. Bone. Joint. Surg. Am. 84: 454-464.

Hamish RD, Steven JB. 2000. A Guide to Canine and Feline Orthopaedic Surgery. 4th Ed. Blackwell Science ltd. Blackwell Publishing Company.
Haynes RC. 1991. Adrenocorticotropic Hormone. Dalam: Goodman and Gilman's The Pharmacological Basis of Therapeutics. Ed 8. Editor: Gilman, A.G. et al. New York: Pergamon Press. II, Pp. 1443.

Janssens K, Dijke PT, Janssens S, Hul WV. 2005. Transforming growth factor- $\beta 1$ to the bone. Endoc. Rev. 26(6):743-774.

Kaewloet LN. 2008. The Correlation Between Affecting Factors and Wound Healing Rate in Diabetic Foot Ulcer. Faculty of Graduate Studies. Mahidot University. India.

Lorenz HP, Longaker MT. 2005. Wounds: Biology, pathology and management. department of surgery. Ann. Surg. 217(4): 391-396.

Maiorama C, Simon M. 2003. Advanced Techniques for Bone Regeneration with Bio-Oss and Bio-Gide. R.C. Libri, Srl, Milano-Italy. Pp.73-88.

Masulili SLC, Maulani C, Sukardi I. 2008. Evaluasi radiografis cangkok tulang alograft dan membran periosteum pada terapi regenaratif untuk periodontitis agresif. Majalah Kedokteran Gigi. 15(2): 169-174.

Pilitsis JG, Lucas DR, Rengachary SR. 2002. Bone healing and spinal fusion. Neurosurg. Focus. 13(6): article 1.

Plata DV, Scheyer ET, Mellonig JT. 2002. Clinical comparison of an enamel matrix derivative used alone or in combination with a bovine-derived xenograft for treatment of periodontal osseus defect in humans. $J$. Periodontal. 73: 433-440.

Poetker DM, Reh DD. 2010. A comprehensive review of the adverse effects of systemic corticosteroid. Otolaryngol. Clin. N. Am. 43: 753-768.

Puricelli E, Corsetti A, Ponzoni D, Martins GL, Leite GM, Santos LA. 2010. Characterization of bone repair in rat femur after treatment with calcium phosphate cement and autogenous bone graft. J. Head Face Med. 6: 10. 
Ratna S. 2011. Kortikosteroid dalam tata laksana uveitis: mekanisme kerja, aplikasi klinis dan efek samping. $J$. Indon. Med. Assoc. 61(6): 265-269.

Rozman P, Bolta Z. 2007. Use of platelet growth factor in treating wounds and soft tissue injuries. Acta. Dermatovenerol. Alp. Pannonica. Adriat. 16(4):156-165.

Smith, E.L., Hill, R.L., Lehman, I.R., Lefkowitz, R.J., Handler, P. And White, A. 1983. Priciples of Bichemistry : Mamalian Biochemistry. Ed. 7. MacGraw Hill Book Co. New York. Pp. 441-467.

Stephan EB, Jang D, Lynch S, Bush P, Dziak R. 1999. Anorganic bovine bone supports osteoblastic cell attachment and proliferation. J. Periodontal. 70: 364-369.

Tzakas P, Wong BYL, Logan AG, Rubin LA, Cole DEC. 2005. Transforming growth factor beta-1 (TGFB-1) and peak bone mass: Association between intragenic polymorphisms and quantitative ultrasound of the heel. BMC. 6: 29.

Virolainen P, Elima K, Metsaranta M, Aro HT, Vuorio E. 1998. Incorporation of cortical bone allografts an autografts in rats. Expression patterns of mRNAs for the TGF-ßs. Acta. Orthop. Sacnd. 69(5): 537-544.

Werner, S and Grose, R. 2003. regulation of wound healing by growth factors and cytokines. London research institute. London. United Kingdom. Physiol. Rev 83: 835-870
Wildmann B, Kadow RA, Haas NP, Schmidmaier G. 2007. Quantification of various growth factors in different demineralized bone matrix preparation. J. Biomed Mater. Res. A. 81(2): 437442.

Wu CH, Yang MY, Chan KC, Chung PJ, Ou TT, Wang CJ. 2010. Improvment in high fat diet induced obesity and body fat accumulation by a nelumbo nucifera leaf flavonoid-rich extract in mice. J. Agris. Food Cem. 58(11): 7075-7081.

Yasear AY, Hamouda SA. 2009. Effect of Dexamethasone on Osteoclast Formation in The Alveolar Bone of Rabbits. Iraqi J. Vet. Sci. 23(1): 13-16.

Yunanthi RAE, Soesilowati ASK, Murdiastuti K. 2010. Perbedaan efektivitas antara demineralized freezedried bone allograft dan demineralized freeze-dried bovine bone xenograft pada perawatan kerusakan intraboni. $J$. Kedokteran Gigi. (1): 45-54.

Yuniarti, W.M., Yudaniayanti, I.S. dan Triakoso, N. 2008. Pengaruh Pemberian Suplemen Kalsium Karbonat Dosis Tinggi pada Tikus Putih Ovariohisterektomi terhadap Mineralisasi Ginjal. J. Vet. Vol 9, No.2: 73-78.

Yuniwarti EYW, Saraswati T. 2002. Aktifitas kalsifikasi tulang tibia broiler jantan dan betina setelah pemberian 1,25-dehidroxycholecalcifeol. Laporan penelitian dosen muda, Universitas Diponegoro, Semarang. 